\title{
The Behaviour of Earnings, Accruals and Impairment Loss of Failed New Zealand Finance Companies*
}

\author{
M. Humayun Kabir** \\ Faculty of Business, Auckland University of Technology, Auckland, New Zealand \\ Fawzi Laswad \\ School of Accountancy, Massey University, Palmerston North, New Zealand
}

Citation:

Kabir, H. and Fawzi L. 2014. The behaviour of earnings, accruals and impairment loss of failed New Zealand finance companies. Australian Accounting Review, 24 (3), 262-275. doi: 10.1111/auar.12028

\section{Brief summary at a glance}

This paper examines the behaviour of earnings, accruals and impairment losses of failed finance companies in New Zealand. It finds that earnings and accruals declined and impairment losses increased significantly in the annual financial statements immediately preceding the companies' failure.

\begin{abstract}
This study examines the behaviour of earnings, accruals and impairment losses of failed finance companies in New Zealand. The paper draws on conservatism in the development of research hypotheses about accounting variables that are likely to contain clues to future failures of finance companies. The hypotheses are tested by examining the trend of earnings after tax (EAT), accruals and impairment loss of 32 finance companies that failed during 2006-11. Data were collected from the annual reports of the sampled companies and the first reports of receivers of failed companies.

The study found that EAT and accruals declined, and impairment loss increased significantly in the last two financial statements prior to failure, when compared with other years. This suggests that changes in EAT, accruals and impairment losses may provide indications of impending failure. The sample size is small.

Investors, managers, auditors, trustees and analysts of finance companies may find the results useful in assessing the going concern status of finance companies. Prior studies investigated mostly non-financial companies. This paper fills this gap in the literature by focusing on finance companies. Further, in contrast with prior studies, the study draws on conservatism in the development of the research hypotheses.
\end{abstract}

JEL Classification Code: M41, M42

Keywords: Business failure, Conservatism, Finance companies, New Zealand

*Humayun Kabir is a Senior Lecturer of financial accounting at Auckland University of Technology. His research interests are in financial reporting and corporate governance. Fawzi Laswad is a Professor and Head of School of Accountancy at Massey University. The 
authors thank two anonymous reviewers for their constructive comments on an earlier draft of this paper, are grateful to Rowena Sinclair of Auckland University of Technology for drawing their attention to Chiang and Prescott (2010) and appreciate the feedback provided at a seminar at the Auckland University of Technology.

**Correspondence: M. Humayun Kabir, Private Bag 92006, AUT University, Auckland 1142, New Zealand. E-mail: humayun.kabir@aut.ac.nz 


\section{The Behaviour of Earnings, Accruals and Impairment Loss of Failed New Zealand Finance Companies}

\section{Introduction}

This study examines the behaviour of earnings, accruals and impairment loss of failed finance companies in New Zealand. The recent procession of many finance companies to failure and the consequent massive losses borne by investors sparked controversy and anger among investors, and caught the attention of regulators and the media. ${ }^{1}$ The Financial Markets Authority and the Serious Fraud Office laid charges against many directors of the failed finance companies and some directors were found guilty and received jail terms. ${ }^{2}$ The collapse of finance companies has also imposed costs on auditors. ${ }^{3}$

Assessing potential corporate failure of finance companies is thus important to investors, monitors (e.g., trustees, auditors), regulators and analysts. There is an extensive literature on bankruptcy prediction models. Most studies (e.g., Altman 1968; Gentry et al. 1985; Grice and Ingram 2001; Pompe and Bilderbeek 2005; Wu et al. 2010) investigate non-financial firms. Finance companies differ from manufacturing companies in important aspects.

Finance companies take deposits from investors and extend loans and advances to customers and businesses. Interest and principal from borrowers are used to pay interest and repay the principal to the investors. Loans, advances and receivables constitute the major portion of the total assets and interest is the main source of revenue for finance companies. Thus, finance companies are different from non-financial companies. Prior studies have predominantly investigated the failures of manufacturing companies and their findings may not be generalisable to finance companies.

Prior studies focused on developing multivariate bankruptcy prediction models based on statistical criteria. However, this paper draws on conservatism to identify variables that are likely to contain clues to potential future failures of finance companies. Hence, this study complements and extends the literature on corporate failures.

The study sample is comprised of 32 finance companies that failed during 2006-11. The results indicate that, when compared with other years, earnings and accruals declined and impairment loss increased significantly in the last two annual financial statements immediately prior to their failure. The results hold for two sub-samples of failed finance companies - 17 property finance companies that failed during and after 2008, and 10 
finance companies whose last audit reports included going concern qualifications. Thus, an analysis of trends of changes in earnings, accruals and impairment loss may provide clues to future corporate failures.

The results are of potential interest to investors, analysts, lenders, auditors, managers and trustees who are concerned with going concern status of finance companies. The results are consistent with the claim in the literature that conditional conservatism is beneficial to debtholders and creditors (Watts 2003a, 2003b; Zhang 2008), and they may be of interest to academics and accounting standard setters.

The remainder of the paper is organised as follows. Section 2 provides a brief review of the literature on the prediction of corporate failure and develops the hypotheses. Section 3 describes the testing of hypotheses and section 4 discusses the sample and data. Section 5 presents the findings and section 6 reports the results of additional analyses. Section 7 reports the results of a sample of non-failed finance companies and the last section concludes and discusses the implications of the findings.

\section{Literature review and hypotheses}

Since the seminal work of Beaver (1966), an extensive literature on the prediction of corporate failure has emerged. The focus of this literature has been mainly on the development of multivariate models of bankruptcy prediction (Altman 1968; Ohlson 1980; Zmijewski 1984; Grice and Ingram 2001; Shumway 2001; Hillegeist et al. 2004; Beaver et al. 2005; Pompe and Bilderbeek 2005; Wu et al. 2010). These models used various accounting and market-based variables. While the models are statistically complex and might be useful to sophisticated users such as auditors (Kuruppu et al. 2012), they may be less useful to other users.

This study differs from prior studies in two respects. First, prior studies (e.g., Altman 1968; Gentry et al. 1985; Grice and Ingram 2001; Pompe and Bilderbeek 2005; Wu et al. 2010) mainly focused on bankruptcy prediction of non-financial firms. Studies on financial distress of finance companies are sparse. Since the financial and operating activities of finance firms differ from manufacturing firms, the results of earlier studies may not be generalised to finance companies. ${ }^{4}$ This paper fills this gap in the literature and examines finance companies. Second, prior studies used diverse criteria (e.g., statistical analysis, simplicity) to select relevant predictor variables (Ohlson 1980; Gentry et al. 1985; Grice and 
Ingram 2001; Pompe and Bilderbeek 2005). In contrast, this study explicitly draws on the concept of conservatism to derive hypotheses about accounting variables that are likely to contain clues about future corporate failures.

Conservatism has been a pivotal feature of accrual accounting. Prior research distinguishes between conditional conservatism and unconditional conservatism (Beaver and Ryan 2005). The application of accounting methods and policies where potential losses are recognised earlier than similar gains is labelled 'conditional' conservatism. Examples include lower-of-cost or market rule under NZ IAS 2 and impairment loss of assets under NZ IAS 36 (NZASB 2011a, 2011b). 'Unconditional' conservatism is the adoption of accounting methods and policies that reduce earnings and book value of net assets independent of economic news. Examples include the immediate expensing of expenditures in the research phase of a project under NZ IAS 38 (NZASB 2011C).

Conditional conservatism sets a higher reliability threshold for the recognition of good news than for bad news in earnings (Basu 1997; Watts 2003a, 2003b). As a result of conditional conservatism, earnings recognise bad news earlier than good news. Prior research suggests that conditional conservatism in earnings is reflected though accruals rather than through cash flows from operating activities (Pae 2007). Thus, earnings and accruals are likely to precede cash flows from operating activities in reflecting bad news.

The failure of a finance company is an extreme form of financial distress and, hence, indicates bad news. Conditional conservatism suggests that earnings and accruals are likely to reflect this financial distress in a timelier manner than cash flows. This suggests that earnings and accruals are likely to decline in the years immediately prior to the failure more so than in other years. This leads to the first two hypotheses:

H1. Earnings of failed finance companies are likely to decline more in the years immediately preceding failure than in other years.

H2. Accruals of failed finance companies are likely to decline more in the years immediately preceding failure than in other years.

The main business of a finance company is to act as an intermediary between lenders and borrowers. Loans, advances and receivables constitute the major asset of the finance company and interest from lending is the major source of revenue. The mean (median) ratio 
of loans, advances and receivables to total assets and the mean (median) ratio of interest revenue to total revenue were $0.83(0.85)$ and $0.74(0.76)$, respectively, for our sample firms during the study period. Thus, the ability of a finance company to continue as a going concern critically depends on the quality of its assets (loan and advances). One major accounting indicator of the quality of such assets is bad debts expense and impairment losses.

Writing off assets as impairment loss is an example of conditional conservatism (Beaver and Ryan 2005; Pae 2007). Impairment loss of loans, receivables and advances is recognised on a timely basis. Hence, recognised impairment loss is likely to precede cash flow problems that eventually result in the distress of a finance company. For example, when a loan is impaired and an impairment loss is recognised on that loan, this predicts that either the future receipt of interest revenue and principal from the borrower would be less than the originally expected amount or the recovery would be delayed. Thus, recognising an impairment loss is likely to be an indicator of future cash flow problems and an early sign of financial distress.

Most of our sample firms either provided finances to the property sector or had their loans and advances backed by property mortgages. The property market was depressed for the most part of the study period. For example, the Real Estate Institute of New Zealand statistics show that the annual percentage change in housing price index was negative during 2008-2009 and 2011. ${ }^{5}$ This potentially reduced the capacity of finance companies' borrowers to repay loans and interest. Thus, impairment losses immediately prior to the failure of finance companies are likely to be higher than in earlier years. This leads to the third hypothesis:

H3. Impairment losses of failed finance companies are likely to be higher in the years immediately preceding failure than in other years.

\section{Testing of hypotheses}

Hypotheses 1 and 2 predict declining earnings and accruals and hypothesis 3 predicts increasing impairment losses in the annual financial statements immediately preceding failure. Since the hypotheses are expressed in terms of the trends of three variables, the 
study examines the trends of the mean and median changes in earnings after tax $(\triangle \mathrm{EAT})$, accruals ( $\triangle \mathrm{ACC}$ ) and impairment losses ( $\triangle \mathrm{IMPLOSS}$ ) of the failed companies prior to failure.

The study uses the last annual financial statements before failure announcement to establish timing and designates such financial statements as t1. The second to last annual financial statements prior to failure are designated as $t 2$, and the third as $t 3$, and so on. The year of failure or the year before failure may not coincide with $t 1$, as the gap between the last annual report and failure announcement varies across companies in the sample. For example, the balance sheet date of Bridgecorp Limited was June 30. Its failure was announced on 2 July 2007 while its last annual report for the year ending 30 June 2006 was published on 29 November 2006. Thus, t1 for Bridgecorp Limited covers the period that ended on 30 June 2006. Out of the 32 failed companies, the last annual reports of 13 failed companies covered the annual period immediately preceding the year of failure and the last annual reports of the remaining 19 failed companies covered the annual period two years prior to the year of failure. The study examines trends of the mean and median $\triangle E A T, \triangle A C C$ and $\triangle I M P L O S S$ of the failed companies in the last four published annual financial statements prior to failure, i.e., during the period t1-t4.

Since the same firms enter the sample in each of the four years $t 1-t 4$, the measurements of the three variables $-\triangle E A T, \triangle A C C$ and $\triangle I M P L O S S$ - during each of the four years are not independent. Hence, we use repeated measures ANOVA F-statistic and the non-parametric Friedman test statistic to test for differences in means and medians of the variables. The Mauchly's Test of Sphericity shows that the sphericity assumption has been violated. Hence, we report the repeated measures ANOVA F-statistics with Greenhouse-Geisser corrections in the paper.

We also calculate the averages of three variables $-\triangle E A T, \triangle A C C$ and $\triangle I M P L O S S-$ for each sample firm for the two periods immediately prior to failure (i.e., t1 and t2) and the two preceding years (i.e., $\mathrm{t} 3$ and $\mathrm{t} 4$ ), and then test for the differences in the means and medians of each matched pair for each of three variables $-\triangle E A T, \triangle A C C$ and $\triangle I M P L O S S$. The following example illustrates this calculation. The $\triangle E A T$ of a company was 0.04 in $\mathrm{t} 4,0.06$ in $\mathrm{t} 3,-0.03$ in $\mathrm{t} 2$, and -0.05 in $\mathrm{t} 1$. The average $\triangle \mathrm{EAT}$ of the company was 0.05 in $\mathrm{t} 3$ and $\mathrm{t} 4$, and 0.04 in $\mathrm{t} 1$ and $\mathrm{t} 2$. We repeat the process for all three variables for each sample company. Thus, we have one matched pair for each variable and test for the differences in means and 
medians of the matched pair for each variable using matched pair t-test statistic and Wilcoxon Signed-Rank Test statistic.

Following prior studies (Gul et al. 2009; Subramanyam 1996), the accruals are estimated as follows:

$$
\mathrm{ACC}=\mathrm{EAT}-\mathrm{CFO}
$$

where $A C C=$ accruals, EAT $=$ earnings after tax, and CFO $=$ cash flow from operations. $^{6}$ Following prior studies (Gul et al. 2009; Subramanyam 1996), all the variables are deflated by total assets at the end of the year.

Impairment loss (IMPLOSS) is calculated as the total of bad debts expense and impairment loss on loans, advances and receivables. IMPLOSS is deflated by total assets.

\section{Sample and data}

The initial study sample was comprised of 66 failed finance companies listed on the "Deep Freeze List" on the website interest.co.nz. ${ }^{7}$ This list of failed firms has been augmented by one additional failed finance company identified by searching the website of the newspaper, the New Zealand Herald. ${ }^{8}$ Annual reports of failed finance companies were collected from the website of the Companies Office New Zealand. ${ }^{9}$ The sampled companies were required to have annual reports for at least the last five years prior to failure. ${ }^{10}$ Twenty-eight companies had no annual report on the Companies Office New Zealand website and seven had annual reports for less than five years. ${ }^{11}$ This resulted in a final sample of 32 failed finance companies. ${ }^{12}$ Panel A of Table 1 describes the process of deriving the sample while Panel B shows the distribution of failure announcements during the period 2006-2011. The failed finance companies in the sample are listed in Appendix A.

\section{Table 1 about here}

Using the annual reports, receivers' first reports and the case notes of the Serious Fraud Office, we identified 20 of these sample companies as property finance companies. Out of these 20 companies, 17 failed during and after 2008. As mentioned in the hypotheses development section, the property market was depressed during and after 2008. Thus, these 17 companies are likely to provide a better test of the hypotheses than the other 
sample companies. Hence, we report the results for these 17 companies along with the full sample.

Further, the last audit reports of 10 sample companies included explanatory paragraphs for going concern uncertainty. The financial condition of these 10 companies might be more distressed than the rest of sample companies. Hence, we also report the results for these 10 companies along with the full sample. Since the sample size of these two sub-groups failed property finance companies and failed finance companies with going concern explanations in the last audit reports - is small, we report the results of non-parametric tests only for these two sub-groups.

\section{Results}

This section reports the results of the tests of hypotheses. Results on the behaviour of earnings are reported first, followed by accruals. We report the results on impairment loss last.

\section{Earnings}

Table 2 reports the trends of mean and median $\triangle E A T, \triangle A C C, \triangle C F O$ and $\triangle I M P L O S S$ of the failed companies in two panels - Panel A for single years and Panel B for two-year averages. The mean $\triangle \mathrm{EAT}$ was 0.016 in $\mathrm{t} 4,-0.008$ in $\mathrm{t} 3,-0.013$ in $\mathrm{t} 2$ and -0.022 in $\mathrm{t} 1$. Although the repeated measures ANOVA F-statistic test for the differences in the means of $\triangle E A T$ is not

statistically significant at less than 10 percent, it could be argued that the declines in earnings are economically significant. Further, earnings after tax started declining in $\mathrm{t} 3$ and declined for three consecutive years. The lack of statistical significance could be attributed to the small sample size. A similar pattern is observed with respect to the median $\triangle E A T$. The Friedman Test statistic $\left(\chi^{2}\right)$ for difference in median $\Delta E A T$ is not significant at less than 10 percent.

Panel $\mathrm{B}$ shows that the mean (median) $\triangle E A T$ was $0.004(0.002)$ during years $\mathrm{t} 3$ and $\mathrm{t} 4$ and $-0.018(-0.004)$ during years $\mathrm{t} 1$ and $\mathrm{t} 2$. The matched pair t-statistic for the difference in means is not significant while the Wilcoxon test statistic for the difference in medians is significant at less than 1 percent.

Table 2 about here 
The results of a separate analysis of 17 property finance companies that failed during and after 2008 are reported in panels $\mathrm{A}$ and $\mathrm{B}$ of Table 3. Panel $\mathrm{A}$ reveals that the median $\triangle \mathrm{EAT}$ was 0.002 in t4, -0.002 in $\mathrm{t} 3,-0.011$ in $\mathrm{t} 2$ and -0.016 in $\mathrm{t} 1$ (results not reported in the table). The Friedman Test statistic $\left(\chi^{2}\right)$ for difference in median $\Delta E A T$ is significant at less than 5 percent. Similarly, panel B shows that the median $\triangle E A T$ was -0.000 in $\mathrm{t} 3$ and $\mathrm{t} 4$ and -0.015 in $\mathrm{t} 1$ and $\mathrm{t} 2$, and the difference in the medians is significant at less than 5 percent. These results are consistent with hypothesis 1.

\section{Table 3 about here}

The results of a separate analysis of 10 finance companies whose last audit reports contained explanatory paragraphs for going concern uncertainty are reported in panels C and $\mathrm{D}$ of Table 3. Panel $\mathrm{C}$ reveals that the median $\triangle \mathrm{EAT}$ was 0.012 in $\mathrm{t} 4,-0.005$ in $\mathrm{t} 3,-0.004$ in $\mathrm{t} 2$ and -0.051 in $\mathrm{t} 1$ (results not reported in the table). The Friedman Test statistic $\left(\chi^{2}\right)$ for difference in median $\triangle E A T$ is significant at less than 10 percent. Similarly, panel $D$ reports that the median $\triangle \mathrm{EAT}$ was 0.001 in $\mathrm{t} 3$ and $\mathrm{t} 4$ and -0.025 in $\mathrm{t} 1$ and $\mathrm{t} 2$. Although the difference in the medians is not statistically significant at less than 10 percent, the difference is economically significant. Taken together, the results support hypothesis 1.

\section{Accruals}

The trends of the mean and median $\triangle \mathrm{ACC}$ of failed finance companies were very similar to those of mean and median $\triangle E A T$. The mean $\triangle A C C$ was -0.007 in t4, 0.028 in t3, -0.059 in t2 and -0.076 in t 1 . Thus, accruals started declining in t 2 and the magnitudes of declines in ACC in year t2 and t1 are economically significant. The difference in the mean $\triangle A C C$ was significant at less than 5 percent. A very similar pattern is observed with respect to the median $\triangle A C C$, and the Friedman Test statistic $\left(\chi^{2}\right)$ for the difference in median $\triangle A C C$ is significant at less than 5 percent. These results are consistent with hypothesis 2. Panel B shows that the accruals of failed companies declined during t1 and t2. For example, the mean (median) $\triangle A C C$ was $0.011(-0.000)$ during $\mathrm{t} 3$ and $\mathrm{t} 4$, and $-0.068(-0.008)$ during $\mathrm{t} 1$ and t2. Further, the difference in mean (median) $\triangle A C C$ is significant at less than 1 percent (5 percent). These findings support hypothesis 2 and suggest that changes in accruals provide early warning signals for impending failures of finance companies. The results are 
consistent with prior research (Pae 2007) that conservatism in earnings is exercised through accruals.

Panel A of Table 3 shows that the median $\triangle A C C$ of 17 property finance companies that failed during and after 2008 was 0.001 in $\mathrm{t} 4,0.008$ in $\mathrm{t} 3,-0.005$ in t2, and -0.074 in $\mathrm{t} 1$. The Friedman Test statistic $\left(\chi^{2}\right)$ for difference in median $\triangle A C C$ is significant at less than 5 percent. Similarly, Panel B reports that the median $\triangle A C C$ was 0.002 in $\mathrm{t} 3$ and $\mathrm{t} 4$, and -0.046 in $\mathrm{t} 1$ and $\mathrm{t} 2$, and the difference in the medians is significant at less than 1 percent. These results are strongly consistent with hypothesis 2 .

Panel $\mathrm{C}$ of Table 3 shows that the median $\triangle \mathrm{ACC}$ of 10 finance companies that received going concern qualification in their last audit reports was 0.005 in $\mathrm{t} 4,0.010$ in $\mathrm{t} 3,-0.012$ in t2 and -0.076 in $\mathrm{t} 1$. The Friedman Test statistic $\left(\chi^{2}\right)$ for difference in median $\triangle A C C$ is significant at less that 5 percent. Similarly, panel $\mathrm{D}$ reveals that the median $\triangle \mathrm{ACC}$ was 0.000 in $\mathrm{t} 3$ and $\mathrm{t} 4$ and -0.081 in $\mathrm{t} 1$ and $\mathrm{t} 2$, and the difference in the medians is significant at less than 10 percent. Taken together, the results strongly support hypothesis 2 .

We also calculated the median changes in working capital accruals ( $\triangle W C A C C$ ) of the failed companies during the study period. Untabulated results show that the median $\triangle W C A C C$ was 0.000 in $\mathrm{t} 4,0.006$ in $\mathrm{t} 3,-0.000$ in $\mathrm{t} 2$, and -0.004 in $\mathrm{t} 1$. The median $\triangle \mathrm{WCACC}$ was negative in $\mathrm{t} 2$ and $\mathrm{t} 1$ indicating that the median changes in WCACC in the last two annual financial statements were income-decreasing; the differences in medians are not statistically significant at less than 10 percent, however. Further, the median $\triangle$ WCACC declined from 0.001 in $\mathrm{t} 3$ and $\mathrm{t} 4$ to -0.005 in $\mathrm{t} 1$ and $\mathrm{t} 2$, and the difference in medians was significant at less than 10 percent.

\section{Impairment Losses}

The mean $\triangle I M P L O S S$ of failed finance companies was 0.001 in t4, 0.009 in $\mathrm{t} 3,0.023$ in $\mathrm{t} 2$ and 0.052 in t1. Thus, impairment losses increased significantly in t2 and t 1 . The difference in the mean $\triangle I M P L O S S$ is significant at less than 10 percent. A similar pattern is observed with respect to the median $\triangle I M P L O S S$ and the difference in the median $\triangle I M P L O S S$ is significant at less than 10 percent. These results support hypothesis 3.

Panel B shows that the mean (median) DIMPLOSS was 0.005 (0.000) during years $\mathrm{t} 3$ and t4, and 0.038 (0.002) during t1 and t2. The matched pair t-statistic (Wilcoxon test statistic) 
for the difference in mean (median) $\triangle$ IMPLOSS is significant at less than 5 percent (1 percent). Again, these results are consistent with hypothesis 3.

Panel A of Table 3 shows that the median $\triangle$ IMPLOSS of 17 property finance companies that failed during and after 2008 was 0.000 in t4, 0.000 in t3, 0.005 in $\mathrm{t} 2$ and 0.023 in $\mathrm{t} 1$. The Friedman Test statistic $\left(\chi^{2}\right)$ for difference in median $\triangle$ IMPLOSS is significant at less than 1 percent. Similarly, panel B reports that the median $\triangle I$ MPLOSS was 0.000 in t3 and t4 and 0.012 in $\mathrm{t} 1$ and $\mathrm{t} 2$, and the difference in the medians is significant at less than 1 percent. These results are strongly consistent with hypothesis 3.

Panel $\mathrm{C}$ shows that the median $\triangle \mathrm{IMPLOSS}$ of 10 finance companies with going concern explanatory paragraphs in their last audit reports was 0.000 in t4, -0.001 in t3, 0.013 in t2 and 0.059 in $\mathrm{t} 1$. The Friedman Test statistic $\left(\chi^{2}\right)$ for difference in median $\Delta$ IMPLOSS is significant at less than 1 percent. Similarly, panel D reveals that the median $\triangle$ IMPLOSS was 0.000 in $\mathrm{t} 3$ and $\mathrm{t} 4$, and 0.033 in $\mathrm{t} 1$ and $\mathrm{t} 2$, and the difference in the medians is significant at less than 1 percent. Taken together, the results strongly support hypothesis 3.

\section{Additional analyses}

Given the results reported in Table 2, we identified two further relevant questions. First, did the CFO of the failed companies decline in the last annual financial statements prior to failure? The second question is whether the failed companies managed loan impairment loss in the last annual financial statements prior to failure.

The first question is interesting in light of a decline in earnings and accruals and an increase in loan impairment loss consistent with the conditional conservatism prediction. Since prior research suggests that conditional conservatism is implemented through accruals rather than CFO (Pae 2007), it would be interesting to examine the trend of CFO prior to failure. The second question is relevant because loans, advances and receivables constitute the major asset of a finance company and impairment loss is an important indicator of the quality of this asset. The literature suggests that managers tend to manage important financial statement numbers to conceal their financial difficulties (Zekany et al. 2004; Albrecht et al. 2009; Schilit and Perler 2010; Fridson and Alvarez 2011). ${ }^{13}$ Thus, managers of failed finance companies had incentives to manage loan impairment loss to give a favourable impression of the performance of its loans and advances. While both the mean and median $\triangle I M P L O S S$ increased over the years prior to failure and the differences 
are statistically significant, the magnitude of median $\triangle I M P L O S S$ is very small. In the light of the small magnitude of median $\triangle I M P L O S S$ prior to failure, it is imperative to ask whether managers of failed finance companies understated loan impairment loss prior to failure. This section examines these two questions.

\section{Did the CFO of failed companies decline prior to failure?}

Table 2 reports the trends of mean and median $\Delta$ CFO. The mean (median) $\Delta$ CFO was 0.023 $(0.012)$ in $t 4,-0.037(-0.004)$ in $t 3,0.046(0.004)$ in t2 and $0.054(0.009)$ in t1. Thus, CFO increased in $\mathrm{t} 2$ and $\mathrm{t} 1$. Both parametric and non-parametric test statistics show that the mean and median changes in CFO are significant at 5 percent and 10 percent, respectively. We obtain similar results when we compare the mean and median changes in CFO during t1 and $\mathrm{t} 2$ with those in $\mathrm{t} 3$ and $\mathrm{t} 4$ although the Wilcoxon test statistic for the difference in median $\triangle C F O$ is not significant at less than 10 percent. The median $\Delta C F O$ of 17 failed property finance companies and 10 failed finance companies whose last audit reports included explanatory paragraphs for going concern uncertainty shows a very similar trend although the differences in medians are not statistically significant. Overall, these results suggest that changes in reported CFO do not provide early warning signals for impending failure. Taken together, these results further suggest that earnings, accruals and loan impairment loss precede cash flow from operation in reflecting bad news.

In light of the failure of the sample companies, one would expect declining CFO in the years immediately preceding failure. Thus, increases in reported CFO of the failed firms prior to failure are contrary to expectation. One plausible explanation is management of CFO prior to failure. This explanation is consistent with the literature that suggests that managers tend to manage important financial metrics to conceal financial difficulties from investors (Schilit and Perler 2010).

To investigate whether the failed companies managed CFO, we compared the components of CFO of each company during the sample period. Our comparison reveals that 10 sample companies either inflated their CFO or reversed the trend of changes in CFO in at least one of the last two annual financial statements by changing the classification of changes in loans, advances and receivables. ${ }^{14}$ The sample companies, including these 10 companies, classified changes in loans, advances and receivables as an investing cash flow.

However, the 10 companies changed their classification from investing cash flow to 
operating cash flow in the last annual financial statements prior to failure. Since the sample companies were facing financial distress, collections of existing loans, advances and receivables exceeded new loans, advances and receivables. In other words, the net change in loans, advances and receivables was positive immediately prior to failure. The reclassification of changes in loans, advances and receivables from investing to operating cash flow had a positive impact on CFO and its trend in the last annual financial statements. This was the major reason for the increase in reported CFO in t2 and t1 in Table $2 .{ }^{15}$

For example, the reported CFO of Mutual Finance was $\$ 0.268$ million in $\mathrm{t} 5, \$ 0.306$ million in $\mathrm{t} 4, \$ 0.285$ in $\mathrm{t} 3, \$ 4.337$ million in $\mathrm{t} 2$ and $\$ 3.190$ million in $\mathrm{t} 1$. The company classified the net change in finance receivables as investing cash flow until $t 3$, but changed its classification to operating cash flow in $\mathrm{t} 2$ and $\mathrm{t} 1$. The net change in finance receivables was $\$ 3.932$ million and $\$ 3.874$ million in $\mathrm{t} 2$ and $\mathrm{t} 1$. If we adjust the reported CFO for this reclassification, the adjusted CFO becomes $\$ 0.405$ million and $-\$ 0.684$ million in $\mathrm{t} 2$ and $\mathrm{t} 1$, respectively. However, besides these 10 sample companies that had an increase in CFO in the last annual financial statements prior to failure, there was one sample company that had a decline in CFO in the last annual financial statements prior to failure as a result of the reclassification in t1. ${ }^{16}$

Besides the reclassification, our comparison revealed two more reasons for the observed increase in reported CFO in the last annual financial statements prior to failure. One company did not deduct interest paid to calculate CFO in t1, despite its deduction in prior years, to arrive at CFO and the presence of interest expense in $\mathrm{t} 1 .{ }^{17}$ One company's CFO increased in $\mathrm{t} 1$ because of an increase in group membership in $\mathrm{t} 1 .{ }^{18}$

We adjusted the reported CFO for the reclassification of the net change in loans, advance and receivables and the non-deduction of interest payment. The mean (median) adjusted $\Delta C F O$ (deflated by total assets) was $0.022(0.011)$ in $\mathrm{t} 4,-0.011(-0.001)$ in $\mathrm{t} 3,0.013(0.003)$ in t2 and $-0.034(-0.010)$ in $\mathrm{t} 1$. The adjusted CFO declined in t1, i.e., in the last annual financial statements prior to failure. However, there was no declining trend of $\triangle \mathrm{CFO}$ during the four years prior to failure. In contrast, as Table 2 shows, earnings and accruals started declining in $\mathrm{t} 3$ and $\mathrm{t} 2$, respectively, and loan impairment loss started increasing in $\mathrm{t} 3$. Thus, we find that earnings, accruals and impairment loss recognise bad news and provide warning signals about impending failure earlier than CFO. 


\section{Did the failed companies manage impairment loss?}

To examine whether failed companies managed loan impairment losses, we assess the first report released by the receiver. Pursuant to Section 24 of the Receiverships Act 1993, the receiver has to release a report not later than two months after the end of each period of six months after his/her appointment as receiver. The report discusses the financial status of the companies under receivership and sometimes indicates an initial estimate of the amount to be returned to secured debenture-holders or creditors. The receiver's first report is released about one year after the publication of the last financial statements of the failed companies. It is the earliest public report after the last publicly available financial statements. We estimate the amount of understatement of loan impairment loss using the following formula.

Understatement of $\quad=$ Total assets at the date of receivership - (amount of secured loan impairment loss debentures*estimated percentage of return to the secured debenture-holders)

For clarity, the formula is illustrated in the following example. An entity has total assets of $\$ 1000$ and secured debentures of $\$ 800$. The receiver initially estimates that secured debenture-holders would get 20 cents to 35 cents per dollar of debenture investment. Hence, the initial estimate of the maximum amount to be returned to secured debentureholders is $\$ 280(=\$ 800 * 0.35)$. This is the amount the receiver estimates to be able to realise from all the assets of the company ${ }^{19}$. This suggests an impairment loss of $\$ 720(=\$ 1000-$ $\$ 280)$. Since the total assets of $\$ 1000$ represent the book value of total assets (i.e., after allowance for impairment loss), the estimated $\$ 720$ impairment loss is the overstatement of the value of assets in the last statements.

The above estimate is subject to three caveats. First, since the receiver's first report is given around one year after the publication of the last publicly available annual financial statements, the estimated amount of understatement of impairment loss does not directly reflect the amount of understatement in the last publicly available financial statements. However, we argue that if there were any material understatement of loan impairment loss in prior financial statements, it would be revealed in the receiver's first report. In other 
words, any understatement of impairment loss estimated from the receiver's first report would be a result of potential understatement of that loss in previous financial statements.

Second, the $\$ 280$ in the above example represents the collection from all the assets of the company. Thus, $\$ 280$ does not represent the impairment loss of loans and advances only. However, we note that loans and advances constitute a significant percentage of total assets. For example, the mean (median) ratio of loans, advances and receivables to total assets was $0.83(0.85)$ for our sample firms during the study period. Further, other assets include cash whose recoverable amount is the same as its book value. Thus, much of the estimated impairment loss relates to loans and advances.

Third, NZ IAS 39 defines impairment loss as the difference between the carrying amount and the present value of estimated future cash flows (NZASB, 2011d, para 63). There is one major difference between our proxy of impairment loss and the measurement of impairment loss according to NZ IAS 39. We do not discount the cash flows estimated by the receiver. This may bias against finding any impairment loss in this paper.

Absent direct evidence of understatement of impairment loss, our interest in this paper is not in the exact magnitude of understatement of impairment loss but in whether managers understated loan impairment loss in the last financial statements. While model (2) is subject to the above caveats, we argue that it provides valid indirect evidence of whether managers understated loan impairment loss in the last financial statements prior to failure.

We were able to collect the receivers' first reports for 27 of 32 failed sample companies from the website of the Companies Office New Zealand. ${ }^{20}$ One of these reports was released around four years after the firm's failure. Thus, we had 26 usable reports. Receivers' first reports of 14 of these 26 companies did not disclose an initial estimate of how much could be returned to the secured debenture-holders/creditors because of their concern for the potential negative impact on future recoverability of the assets. The remaining 12 reports estimated that secured debenture-holders would get less than 100 percent of their investment. This suggests significant impairment loss. However, since four of these companies did not disclose the total assets at the date of receivership, we could estimate the precise amount of understatement of loan impairment loss of eight companies. ${ }^{21}$ The average magnitude of understatement is $49.16 \%$ of total assets. While this estimate is subject to the caveats mentioned above, the size of the percentage suggests strongly in 
favour of the presence of understatement of loan impairment loss in the last publicly available financial statements.

Details provided in the available receivers' first reports of failed companies also suggest significant understatement of loan loss impairment. For example, the receivers of Capital+Merchant Finance Limited noted in their first report that they believed that the under-recovery provisions of the loan book was understated by at least $43.42 \%$. Receivers of three failed companies (Five Star Consumer Finance Limited, Lombard Finance \& Investments Limited and National Finance 2000 Ltd) noted in their first reports that they considered the allowance for doubtful debts as materially understated and believed that additional significant amount of allowance would be needed. The receivers of Provincial Finance Limited disclosed an allowance for doubtful debts of $30 \%$ for financial receivables as at 31 March 2006. The receivers of Rockforte Finance Limited concluded in the first report that the overdue loans were understated as the company regularly re-financed nonperforming loans into new loans. This had the effect of removing the non-performing loans from the records. The receivers of Western Bay Finance Limited noted in their first report that the provision for doubtful debts of $\$ 2.8$ million was understated by $\$ 3.2-\$ 10.2$ million. They further noted that approximately half of its current loans had been rescheduled, i.e., the loan was outside of the original terms and the original terms had been extended. Taken together, these results are indicative of understatement of loan impairment loss in the last publicly available annual financial statements.

\section{Non-failed finance companies}

Given that earnings and accruals decreased and loan impairment loss increased in the last annual financial statements prior to failure, it would be interesting to assess whether these variables can discriminate between failed and non-failed firms. To examine this question, this study uses a sample of four non-failed finance companies for comparison. Two sources were used to identify the non-failed finance companies. First, the term "finance company" was entered in the search field of the Companies Office New Zealand website. The website returned a list of 200 finance companies, only 38 of which are surviving companies. However, the Companies Office website did not contain any financial statements for any of these surviving 38 companies. The second source is the list of members of the Financial Services Federation. ${ }^{22}$ The list contains the names of 33 financial services companies. The 
financial statements of only seven of these 33 companies are available. The financial statements of two of these seven companies were prepared using the differential reporting framework and do not contain Statements of Cash Flows which does not permit the calculation of accruals. One company does not have data to calculate the change variables $\triangle E A T, \triangle A C C$ and $\triangle I M P L O S S$ - for four years. Thus, only four non-failed companies remain for the comparative analysis. The four non-failed finance companies are listed in Appendix A.

Given the small sample size of non-failed firms and the lack of matching with failed firms, the results of this comparison are tentative. Since the sample size is small, we report only the median of the variables. Although statistical tests may not be meaningful for a sample size of four, we report the statistical significance as a matter of custom.

Table 4 reports the trend of $\triangle E A T, \triangle A C C$ and $\triangle I M P L O S S$ of the surviving companies for the 2007-10 period and designates 2010 as t1, 2009 as t2 and so on. The year 2010 is designated as $\mathrm{t} 1$ for surviving finance companies because it is the year covered by the last publicly available annual financial statements for failed finance companies in the study sample.

\section{Table 4 about here}

Panel A of Table 4 reports the median $\triangle E A T, \triangle A C C$ and $\triangle I M P L O S S$ of non-failed companies. In contrast with the failed companies, the median $\triangle E A T$ declined until t2 but increased in $\mathrm{t} 1$, the median $\triangle \mathrm{ACC}$ increased from $\mathrm{t} 3$ onward, and the median $\triangle \mathrm{IMPLOSS}$ increased in $\mathrm{t} 2$ but declined in $\mathrm{t} 1$. When we compare the median of the change variables $\triangle E A T, \triangle A C C$ and $\triangle I M P L O S S$ - in $\mathrm{t} 1$ and $\mathrm{t} 2$ with those in the preceding two years (i.e., $\mathrm{t} 3$ and t4) in Panel B, we find that the median $\triangle E A T$ and $\triangle A C C$ increased and the median $\triangle I M P L O S S$ declined in the last two financial statements (i.e., $\mathrm{t} 1$ and $\mathrm{t2}$ ). Thus, overall the trends of $\triangle E A T, \triangle A C C$ and $\triangle I M P L O S S$ hypothesised for failed finance firms are not observed for nonfailed firms. These results suggest that the three variables $-\triangle E A T, \triangle A C C$ and $\triangle I M P L O S S-$ may potentially discriminate between failed and non-failed finance firms.

However, the non-failed firms are not matched with the failed firms. Hence, for a better matching between failed and non-failed firms, we performed a separate analysis of the four failed firms that published their last annual reports in 2010. Untabulated results show that the trend of median $\triangle E A T$ was similar to that of the non-failed firms and suggest that 
earnings changes probably cannot discriminate between failed and surviving firms. However, in contrast with the non-failed firms, the trend of changes in accruals was very similar to that of the full sample of failed firms. The results suggest that accruals can potentially discriminate between failed and non-failed firms. The median $\triangle$ IMPLOSS increased till $\mathrm{t} 2$ but slightly declined in $\mathrm{t} 1$. However, the median $\triangle \mathrm{IMPLOSS}$ was 0.000 in $\mathrm{t} 3$ and $\mathrm{t} 4$, and 0.012 in $\mathrm{t} 1$ and $\mathrm{t} 2$. Taken together, these results suggest that loan impairment loss changes can potentially discriminate between failed and non-failed finance firms.

\section{Conclusions and discussion}

This study examined the behaviour of earnings, accruals and impairment loss of failed finance companies in New Zealand. The study is motivated by the substantial losses borne by investors in failed finance companies and the consequent need to find red flags that can provide indicators for potential future corporate failures. The study is further motivated by the absence of studies on the failure of finance companies in the literature.

This paper draws on conservatism to develop hypotheses about potential predictors of the failure of finance companies and indicates that earnings and accruals would decline and impairment loss would increase in the years immediately preceding failure. The sample was comprised of 32 New Zealand finance companies that failed during 2006-11.

The results are consistent with the hypotheses. Accruals declined and impairment loss increased significantly more during the combined $\mathrm{t} 1$ and $\mathrm{t} 2$ than in the combined $\mathrm{t} 3$ and $\mathrm{t} 4$. The magnitudes of declines in accruals and increases in impairment loss during t1 and t2 were economically significant. However, while earnings also declined during $t 1$ and $t 2$, the significance of the difference in mean (median) earnings change depends on the test. The results hold for two sub-samples of failed finance companies - 17 property finance companies that failed during and after 2008 and 10 failed finance companies that received going concern qualifications in their last audit reports before failure. The results for these two sub-samples are consistent with hypothesis 1 . Thus, overall the results support hypothesis 1 which predicts declines in earnings prior to corporate failure.

Additional analyses suggest that reported CFO of failed finance companies increased prior to failure and further investigation shows that managers of some finance companies inflated reported CFO prior to failure by changing the classification of changes in loans, advances and receivables from investing cash flow to operating cash flow prior to failure. 
This paper also provides evidence for a potential understatement of loan impairment loss in the last annual financial statements prior to failure.

A separate analysis of four non-failed firms suggests that accruals and impairment loss can potentially discriminate between failed and non-failed firms. However, given the small sample size of non-failed firms, the findings of the comparison should be taken as tentative.

The paper contributes to the literature in three ways. First, it fills a gap in the literature by examining failure of finance companies. Second, this paper draws on conservatism in the development of the hypotheses about the potential predictors of failures of finance companies. Third, this study documents that failed finance companies inflated CFO and potentially understated loan impairment loss in the last annual financial statements prior to failure.

Managers, auditors, investors, analysts, lenders and trustees may find the results of this study useful in assessing the ability of companies to continue as going concerns. ${ }^{23}$ The findings also suggest that the elimination of conservatism/prudence from the joint conceptual frameworks of the Financial Accounting Standards Board and the International Accounting Standards Board may not serve the interests of creditors and debtholders, and thus are of interest to academics and standard setters. 


\section{Appendix A}

The sample of failed finance companies in New Zealand

\begin{tabular}{|c|c|c|c|}
\hline Finance company Name & Moratorium & $\begin{array}{l}\text { Placed into } \\
\text { receivership }\end{array}$ & $\begin{array}{l}\text { Placed into } \\
\text { liquidation on }\end{array}$ \\
\hline National Finance 2000 Ltd. & & 9 May 2006 & 1 August 2008 \\
\hline Provincial Finance Limited & & 30 May 2006 & \\
\hline Western Bay Finance Limited & & 3 August 2006 & \\
\hline Bridgecorp Limited & & 2 July 2007 & 29 August 2008 \\
\hline Nathans Finance NZ Limited & & 20 August 2007 & \\
\hline Five Star Consumer Finance & & 29 August 2007 & \\
\hline \multicolumn{4}{|l|}{ Limited } \\
\hline Property Finance Securities & & 29 August 2007 & \\
\hline Beneficial Finance & October 2007 & & \\
\hline Capital+Merchant Finance Limited & & 29 November 2007 & 15 December 2009 \\
\hline Numeria Finance & & 17 December 2007 & \\
\hline Lombard Finance \& Investments & & 10 April 2008 & \\
\hline \multicolumn{4}{|l|}{ Limited } \\
\hline Belgrave Finance Limited & & 28 May 2008 & 23 April 2010 \\
\hline IMP Diversified Income Fund & June 2008 & & \\
\hline United Finance Limited & July 2008 & & \\
\hline Hanover Finance Limited & 23 July 2008 & & \\
\hline Dominion Finance Group Limited & & 9 September 2008 & 15 May 2009 \\
\hline Orange Finance & December 2008 & & \\
\hline Mascot Finance & & 2 March 2009 & \\
\hline OPI Pacific Finance Limited & & 15 September 2009 & 3 November 2011 \\
\hline Boston Finance & & 19 November 2009 & \\
\hline Strategic Finance Limited & & 12 March 2010 & 26 July 2010 \\
\hline Vision Securities & & 31 March 2010 & \\
\hline ST Laurence Limited & & 29 April 2010 & \\
\hline Rockforte Finance Limited & & 10 May 2010 & 15 February 2011 \\
\hline North South Finance Limited & & 8 July 2010 & 17 September 2010 \\
\hline Mutual Finance Limited & & 14 July 2010 & \\
\hline Allied Nationwide Finance Limited & & 20 August 2010 & \\
\hline South Canterbury Finance Limited & & 31 August 2010 & \\
\hline Equitable Mortgages Limited & & 29 November 2010 & 14 December 2010 \\
\hline GMAC Financial Services NZ & & & 14 December 2010 \\
\hline \multicolumn{4}{|l|}{ Limited } \\
\hline Finance and Leasing Limited & & 18 January 2011 & \\
\hline NZF Money Limited & & 22 July 2011 & \\
\hline
\end{tabular}

Source: Dates of moratorium are from Chiang and Prescott (2010). Dates of receivership and liquidation have been collected from the receivers' and liquidators' reports. These reports were available at http://www.business.govt.nz/companies. 
The sample of non-failed finance companies

Asset Finance Limited

Avanti Finance Limited

Instant Finance

Prometheus Finance Limited 


\section{References}

Albrecht, W.S., Albrecht, C.C., Albrecht, C.O. and Zimbelman, M.F. 2009, Fraud Examination, Third Edition, South-Western Cengage Learning, Mason, $\mathrm{OH}$.

Altman, E.I. 1968, 'Financial Ratios, Discriminant Analysis and the Prediction of Corporate Bankruptcy', Journal of Finance, 23: 589-609.

Basu, S. 1997, 'The Conservatism Principle and the Asymmetric Timeliness of Earnings', Journal of Accounting and Economics, 24: 3-37.

Beaver, W.H. 1966, 'Financial Ratios as Predictors of Failure', Journal of Accounting Research, 4, 3: 71-111.

Beaver, W.H., McNichols, M.F. and Rhie, J.-U. 2005, 'Have Financial Statements Become Less Informative? Evidence from the Ability of Financial Ratios to Predict Bankruptcy', Review of Accounting Studies, 10: 93-122.

Beaver, W.H. and Ryan, S.G. 2005, 'Conditional and Unconditional Conservatism: Concepts and Modelling', Review of Accounting Studies, 10: 269-309.

Chiang, C. and Prescott, S.M. 2010, 'The Financial Crisis in New Zealand: An Inconvenient Truth', paper presented at Auckland Region Accounting Conference, 26 November 2010, Manukau Institute of Technology, available at http://w3.manukau.ac.nz/aaac/ ARA 2010 papers/Chiang Prescott.pdf last accessed 10 January 2012.

Edwards, J.R. 1989, A History of Financial Accounting, Routledge, London.

Fletcher, H. 2011, 'Bridgecorp Boss Guilty', The New Zealand Herald, 8 October, available at http://www.nzherald.co.nz/news/print.cfm?objectid=10757468 last accessed 30 January 2012.

Fletcher, H. 2012, 'Finance Boss Ludlow Gets Nine Months Extra Jail', The New Zealand Herald, 26 January, available at http://www.nzherald.co.nz/news/print.cfm?objectid= 10781290 last accessed 29 January 2012.

Fridson, M. and Alvarez, F. 2011, Financial Statement Analysis - A Practitioner's Guide, Fourth Edition, Wiley \& Sons, Inc., New Jersey.

Gentry, J.A., Newbold, P. and Whitford, D.T. 1985, 'Classifying Bankrupt Firms with Funds Flow Components', Journal of Accounting Research, 23, 1: 146-160.

Gibson, A. 2011, 'Nathans Finance Directors Guilty', The New Zealand Herald, 8 July, available at http://www.nzherald.co.nz/news/print.cfm?objectid=10737109 last accessed 30 January 2012. 
Graham, J.R., Harvey, C.R. and Rajgopal, S. 2005, 'The Economic Implications of Corporate Financial Reporting', Journal of Accounting and Economics, 40: 3-73.

Grant, D. 2011, 'Duties Abrogated in Murky World of Second-Tier Finance', The New Zealand Herald, 17 July, available at http://www.nzherald.co.nz/news/print.cfm?objectid=10738942 last accessed 30 January 2012.

Gregor, K. 2011, 'John Hotchin Admits Nathans Finance Documents Wrong', The New Zealand Herald, 4 May, available at http://www.nzherald.co.nz/news/print.cfm?objectid= 10723369 last accessed 30 January 2012.

Grice, J.S. and Ingram, R.W. 2001, 'Test of the Generalizability of Altman's Bankruptcy Prediction Model', Journal of Business Research, 54: 53-61.

Gul, F.A., Fung, S.Y.K. and Jaggi, B. 2009, 'Earnings Quality: Some Evidence on the Role of Auditing Tenure and Auditors' Industry Expertise', Journal of Accounting and Economics, 47: 265-287.

Hillegeist, S.A., Keating, E., Cram, D.P. and Lundstedt, J.G. 2004, 'Assessing the Probability of Bankruptcy', Review of Accounting Studies, 9: 5-34.

Kuruppu, N., Laswad, F. and Oyelere, P. 2012, 'Assessing Going Concern: The Practical Value of Corporate Failure Models and Auditors' Perceptions', Pacific Accounting Review, 24, 1: 33-50.

New Zealand Accounting Standards Board (NZASB) 2011a, 'New Zealand Equivalent to International Accounting Standard 2 Inventories (NZ IAS 2)', available at http://www.xrb.govt.nz/Site/Accounting Standards/Current Standards/Standards ForProfit Entities.aspx last accessed 15 December 2011.

New Zealand Accounting Standards Board (NZASB) 2011b, 'New Zealand Equivalent to International Accounting Standard 36 Impairment of Assets (NZ IAS 36)', available at http://www.xrb.govt.nz/Site/Accounting Standards/Current Standards/Standards ForProfit Entities.aspx last accessed 15 December 2011.

New Zealand Accounting Standards Board (NZASB) 2011c, 'New Zealand Equivalent to International Accounting Standard 38 Intangible Assets (NZ IAS 38)', available at http://www.xrb.govt.nz/Site/Accounting Standards/Current Standards/ Standards ForProfit Entities.aspx last accessed 15 December 2011.

New Zealand Accounting Standards Board (NZASB) 2011d, 'New Zealand Equivalent to International Accounting Standard 39 Financial Instruments: Recognition and Measurement (NZ IAS 39)', available at http://www.xrb.govt.nz/Site/Accounting Standards/Current Standards/ Standards ForProfit Entities.aspx last accessed 15 December 2011. 
Nordqvist, S. and Adams, C. 2011, 'Jail for Two Nathans Directors Sends a 'Clear Message", The New Zealand Herald, 3 September, available at http://www.nzherald.co.nz/news/print. cfm?objectid=10749071 last accessed 30 January 2012.

Ohlson, J. 1980, 'Financial Ratios and the Probabilistic Prediction of Bankruptcy', Journal of Accounting Research, 18: 109-131.

Pae, J. 2007, 'Unexpected Accruals and Conditional Accounting Conservatism', Journal of Business Finance \& Accounting, 34, 5 \& 6: 681-704.

Pompe, P.P.M. and Bilderbeek, J. 2005, 'The Prediction of Bankruptcy of Small- and Medium-Sized Industrial Firms', Journal of Business Venturing, 20: 847-868.

PricewaterhouseCoopers (PWC), 2011, 'Receivers' Eighth Report on the State of Affairs of Nathans Finance NZ Limited (in Receivership)', available at http://www.business.govt.nz/ companies/app/ui/pages/companies/1150880/documents?backurl=\%2Fcompanies\%2Fapp \%2Fui\%2Fpages\%2Fcompanies\%2Fsearch\%3Fmode\%3Dstandard\%26type\%3Dentities\%26q \%3DNathans\%2520Finance last accessed 22 February 2012.

Schilit, H.M. and Perler, J. 2010, Financial Shenanigans - How to Detect Accounting Gimmicks \& Fraud in Financial Reports, The McGraw-Hill Companies, New York.

Serious Fraud Office (SFO) 2012a, 'National Finance 2000 Limited: Case No 1616', available at http://sfo.govt.nz/case/national-finance-2000-1616 last accessed 1 February 2012.

Serious Fraud Office (SFO) 2012b, 'Bridgecorp Limited: Case No 1723', available at http://sfo.govt.nz/case/bridgecorp-1723 last accessed 5 February 2012.

Shumway, T. 2001, 'Forecasting Bankruptcy More Accurately: A Simple Hazard Model', Journal of Business, 74: 101-124.

Subramanyam, K.R. 1996, 'The Pricing of Discretionary Accruals', Journal of Accounting and Economics, 22: 249-281.

Watts, R.L. 2003a, 'Conservatism in Accounting Part I: Explanations and Implications', Accounting Horizons, 17, 3: 207-221.

Watts, R.L. 2003b, 'Conservatism in Accounting Part II: Evidence and Research Opportunities', Accounting Horizons, 17, 4: 287-301.

Wu, Y., Gaunt, C. and Gray, S. 2010, 'A Comparison of Alternative Bankruptcy Prediction Models', Journal of Contemporary Accounting \& Economics, 6: 34-45.

Zekany, K.E., Braun, L.W. and Warder, Z.T. 2004, 'Behind Closed Doors at Worldcom: 2011', Issues in Accounting Education, 19, 1: 101-117. 
Zhang, J. 2008, 'The Contracting Benefits of Accounting Conservatism to Lenders and Borrowers', Journal of Accounting and Economics, 45, 27-54.

Zmijewski, M.E. 1984, 'Methodological Issues Related to the Estimation of Financial Distress Prediction Models', Journal of Accounting Research, 22, Supplement: 59-82. 
Table 1

Sample of failed finance companies

Panel A: Sample selection procedure

Number of failed finance companies in Deep Freeze List

Failed finance company not in Deep Freeze List

Less Number of companies with no annual report on Companies Office Website

Less Number of companies with annual report for less than 5 years

28

Final sample

$\underline{7} \quad \underline{35}$

Panel B: Sample firms according to year of failure

\begin{tabular}{lr}
\hline Year of failure & Number of firms \\
\hline 2006 & 2 \\
2007 & 8 \\
2008 & 8 \\
2009 & 1 \\
2010 & 1 \\
2011 & 11 \\
Total & 2 \\
\end{tabular}


Table 2

Trends in earnings ( $\triangle E A T)$, accruals ( $\triangle \mathrm{ACC}$ ), cash flow from operations (CFO) and impairment loss ( $\triangle \mathrm{IMPLOSS}$ ) of failed finance companies

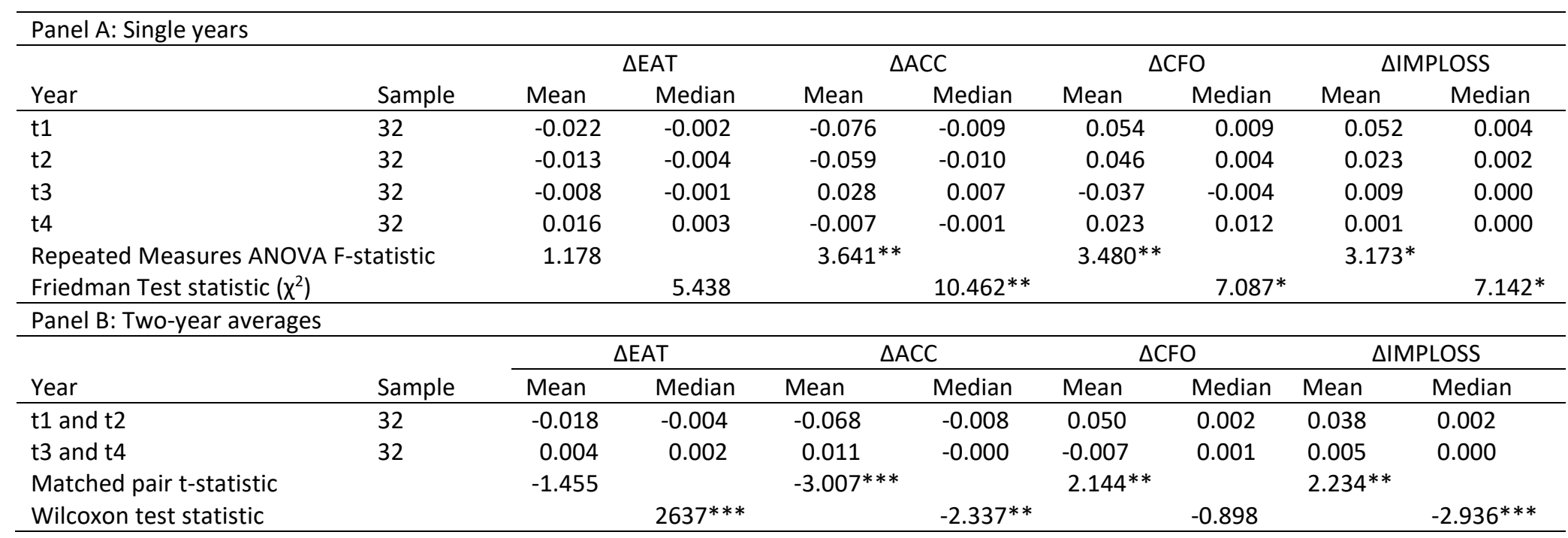

Note:

$\mathrm{ACC}=\mathrm{EAT}-\mathrm{CFO}(1)$

Where

ACC = Accruals; EAT = earnings after tax, and CFO = cash flow from operations. Impairment loss is the total of bad debts expense and impairment loss on loans, advances and receivables. All these variables have been deflated by total assets. $t 1$ stands for the last annual financial statements prior to failure, $t 2$ stands for the second to last annual financial statements prior to failure, and so on.

The Mauchly's test of sphericity shows that the sphericity assumption has been violated. Hence, the Repeated Measures ANOVA F-statistic is with Greenhouse-Geisser correction.

$*, * *$, and $* * *$ indicate statistical significance at 10 percent, 5 percent and 1 percent, respectively. 
Table 3

Trends in earnings ( $\triangle \mathrm{EAT})$, accruals $(\triangle \mathrm{ACC})$, and impairment loss ( $\triangle \mathrm{IMPLOSS}$ ) of sub-samples of non-failed finance companies

\begin{tabular}{|c|c|c|c|c|}
\hline \multicolumn{5}{|c|}{ Panel A Single years - Failed property finance companies } \\
\hline \multirow[b]{2}{*}{ Year } & \multirow[b]{2}{*}{ Sample } & \multirow{2}{*}{$\begin{array}{l}\Delta \text { EAT } \\
\text { Median }\end{array}$} & \multirow{2}{*}{$\frac{\triangle \mathrm{ACC}}{\text { Median }}$} & \multirow{2}{*}{$\begin{array}{l}\text { MIMPLOSS } \\
\text { Median }\end{array}$} \\
\hline & & & & \\
\hline t1 & 17 & -0.016 & -0.074 & 0.023 \\
\hline t2 & 17 & -0.011 & -0.005 & 0.005 \\
\hline t3 & 17 & -0.002 & 0.008 & 0.000 \\
\hline t4 & 17 & 0.002 & 0.001 & 0.000 \\
\hline Friedman Test statistic $\left(\chi^{2}\right)$ & & $8.506 * *$ & $10.271 * *$ & $12.055^{* * *}$ \\
\hline \multicolumn{5}{|c|}{ Panel B Two-year averages - Failed property finance companies } \\
\hline & & $\Delta \mathrm{EAT}$ & $\triangle \mathrm{ACC}$ & $\triangle I M P L O S S$ \\
\hline Year & Sample & Median & Median & Median \\
\hline $\mathrm{t} 1$ and $\mathrm{t} 2$ & 17 & -0.015 & -0.046 & 0.012 \\
\hline t3 and t4 & 17 & -0.000 & 0.002 & 0.000 \\
\hline Wilcoxon test statistic & & $2.533 * *$ & $-2.864 * * *$ & $-2.864 * * *$ \\
\hline \multicolumn{5}{|c|}{ Panel C Single years - Failed finance companies with going concern qualifications in the last audit reports } \\
\hline & & $\triangle \mathrm{EAT}$ & $\triangle \mathrm{ACC}$ & $\triangle \mathrm{IMPLOSS}$ \\
\hline Year & Sample & Median & Median & Median \\
\hline t1 & 10 & -0.051 & -0.076 & 0.059 \\
\hline t2 & 10 & -0.004 & -0.012 & 0.013 \\
\hline t3 & 10 & -0.005 & 0.010 & -0.001 \\
\hline t4 & 10 & 0.012 & 0.005 & 0.000 \\
\hline Friedman Test statistic $\left(\chi^{2}\right)$ & & $6.960 *$ & $8.280 * *$ & $12.125^{* * *}$ \\
\hline \multicolumn{5}{|c|}{$\begin{array}{l}\text { Panel D Two-year averages - Failed finance companies with going concern qualifications in the last audit } \\
\text { reports }\end{array}$} \\
\hline & & $\Delta \mathrm{EAT}$ & $\triangle \mathrm{ACC}$ & $\triangle \mathrm{IMPLOSS}$ \\
\hline Year & Sample & Median & Median & Median \\
\hline t1 and t2 & 10 & -0.025 & -0.081 & 0.033 \\
\hline t3 and t4 & 10 & 0.001 & 0.000 & -0.000 \\
\hline Wilcoxon test statistic & & -1.376 & $-1.886^{*}$ & $-2.803 * * *$ \\
\hline
\end{tabular}

Note:

Panels A and B report results for 17 property finance companies that failed during and after 2008 and panels C and $D$ report results for 10 failed finance companies that received going concern explanatory paragraphs in their last audit reports prior to failure.

$\mathrm{ACC}=\mathrm{EAT}-\mathrm{CFO}(1)$

Where

ACC = Accruals; EAT = earnings after tax and CFO = cash flow from operations. Impairment loss is the total of bad debts expense and impairment loss on loans, advances and receivables. All these variables have been deflated by total assets. $\mathrm{t} 1$ stands for the last annual financial statements prior to failure, $\mathrm{t} 2$ stands for the second to last annual financial statements prior to failure, and so on.

$*, * *$, and $* * *$ indicate statistical significance at 10 percent, 5 percent and 1 percent, respectively. 
Table 4

Changes in earnings ( $\triangle E A T)$, accruals ( $\triangle \mathrm{ACC}$ ) and impairment loss ( $\triangle \mathrm{IMPLOSS}$ ) of non-failed finance companies

\begin{tabular}{|c|c|c|c|c|}
\hline \multicolumn{5}{|l|}{ Panel A Single years } \\
\hline & & $\triangle \mathrm{EAT}$ & $\triangle \mathrm{ACC}$ & $\triangle \mathrm{IMPLOSS}$ \\
\hline Year & Sample & Median & Median & Median \\
\hline t1 (2010) & 4 & 0.020 & 0.028 & -0.010 \\
\hline t2 (2009) & 4 & -0.006 & 0.005 & 0.009 \\
\hline t3 (2008) & 4 & -0.005 & 0.013 & -0.004 \\
\hline t4 (2007) & 4 & -0.004 & -0.006 & 0.005 \\
\hline Friedman Test statistic $\left(\chi^{2}\right)$ & & $7.500 *$ & 2.100 & 4.500 \\
\hline \multicolumn{5}{|l|}{ Panel B Two-year averages } \\
\hline & & $\triangle \mathrm{EAT}$ & $\triangle \mathrm{ACC}$ & $\triangle \mathrm{IMPLOSS}$ \\
\hline Year & Sample & Median & Median & Median \\
\hline t1 and t2 (2010 and 2009) & 4 & 0.003 & 0.023 & -0.000 \\
\hline t3 and t4 (2008 and 2007) & 4 & -0.006 & -0.002 & 0.000 \\
\hline Wilcoxon test statistic & & -1.461 & -1.461 & -0.365 \\
\hline
\end{tabular}

Note:

$\mathrm{ACC}=\mathrm{EAT}-\mathrm{CFO}(1)$

Where

ACC = Accruals; EAT $=$ earnings after tax , and CFO = cash flow from operations. Impairment loss is the total of bad debts expense and impairment loss on loans, advances and receivables. All these variables have been deflated by total assets.

$*, * *$, and $* * *$ indicate statistical significance at 10 percent, 5 percent and 1 percent, respectively. 


\section{Endnotes}

1 For example, National Finance 2000 owed 2000 investors approximately NZ\$21 million (SFO 2012a). Bridgecorp was placed into receivership on 2 July 2007, owing approximately 14500 investors about NZ\$459 million (SFO 2012b). Some investors of National Finance received 49 cents in the dollar while others received nothing (Fletcher 2012). Nathans owed $\$ 174$ million to about 7000 investors (Gregor 2011). By the end of October 2011, the receivers of Nathans could distribute only $3.7 \%$ of the principal investment to secured debenture investors (PWC 2011).

2 For example, former Bridgecorp directors were accused of making untrue statements in their prospectus and misleading investors. On 7 October 2011, Justice Pamela Andrews of the High Court at Auckland sentenced former Bridgecorp Chairman Bruce Davidson to nine months of home detention for misleading investors. The court also asked Davidson to pay $\$ 500000$ in reparations that the court would distribute among Bridgecorp investors and 200 hours of community work (Fletcher 2011). Further, the High Court at Auckland found three directors of Nathans Finance - Mervyn Doolan, Donald Young, and Kenneth (Roger) Moses - guilty on five charges of breaching the Securities Act (Gibson 2011). They were sentenced to jail and home detentions of various durations, were asked to pay financial penalty and do community work (Nordqvist and Adams 2011)

3 For example, the Institute of Chartered Accountants of New Zealand fined the auditor of Nathans Finance $\$ 163000$ (Grant 2011).

$4 \quad$ For example, two widely used variables to predict bankruptcy of manufacturing firms are working capital and market value of equity (Altman 1968; Grice and Ingram 2001). Working capital is not an appropriate variable for the prediction of failure of finance companies. Further, the failed finance companies in our sample were not listed at the time they failed. Hence, market value of equity cannot be used to predict failure of our sample companies.

$5 \quad$ The statistics are available on https://www.reinz.co.nz/reinz/public/reinz-statistics/reinzstatistics home.cfm last accessed 28 January 2013.

$6 \quad$ Prior studies (Gul et al. 2009; Subramanyam 1996) used earnings before extraordinary items to estimate accruals. Since finance companies in our sample do not report any extraordinary items, this study uses earnings after tax to estimate accruals.

7 The Deep Freeze List is available on the internet at http://www.interest.co.nz/saving/deep-freeze-list last accessed 12 September 2012.

$8 \quad$ This initial list of failed finance companies is compared with the sample in Appendix A of Chiang and Prescott (2010). All the failed companies in Chiang and Prescott (2010) are included in the initial list of failed companies of this study.

9 The address of the website is http://www.business.govt.nz/companies.

10 This restriction has been imposed on the sample because many finance companies had very short lives. Further, this restriction is also consistent with Ohlson (1980).

11 Out of these seven companies, one had data for only one year and so change variables could not be calculated for this firm. Another firm was considered outlier and so was excluded. The remaining five firms had data for two to four years. These five firms were included with 32 firms and the same analyses were done for these 37 firms. The results are qualitatively similar to those reported for the 32 firms.

12 While the sample size is small, this study includes all finance companies for which data were available. Further, the sample size is similar to that of Gentry et al. (1985), whose sample comprised 33 failed firms and 33 non-failed firms.

13 Managing accounting numbers is a very old phenomenon. The City of Glasgow Bank understated liabilities, overstated assets and inflated earnings in its last financial statements published on 5 June 1878 (Edwards 1989: 145). The Royal Mail Steam Packet Company boosted profits during 1921-29 using secret reserves before the group collapsed (Edwards 1989: 150).

14 These companies are Allied Nationwide Finance Limited, Equitable Mortgages Limited, GMAC Financial Services NZ Limited, Mutual Finance, North South Finance Limited, NZF Money Limited, Orange Finance, Rockforte Finance Limited, ST Laurence Limited and Strategic Finance Limited. 
15 The literature documents that managers manage accounting numbers by exercising both accounting discretion and real discretion (Graham et al., 2005). Thus, in addition to re-classification of changes in loans and advances, real actions might have been taken by failed finance companies to inflate their CFO prior to failure. The company was Vision Securities. Its reported CFO and adjusted CFO in t1 were $-\$ 6.884$ million

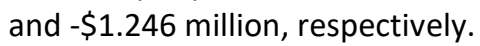

17 The company was Boston Finance. The name of the company was Equitable Mortgages Limited. Equitable Property Mortgage Fund was part of the group in $\mathrm{t} 1$ but not in $\mathrm{t} 2$. The money collected from the realisation of assets is used to repay the amount owing to the debentureholders as well as the receiver's fee. The receivers' reports can be accessed from the website of Companies Office New Zealand: http://www.business.govt.nz. The companies are Belgrave Finance Limited, Bridgecorp Limited, Capital+Merchant Finance Limited, Five Star Consumer Finance Limited, Lombard Finance \& Investments Limited, National Finance 2000 Ltd., Numeria Finance, and Western Bay Finance Limited. The list is available on http://www.fsf.org.nz/Site/Membership/Full Member List.aspx. The website was accessed on 9 October 2012. Investors may rely on the auditors and trustees to monitor management. But these monitors may fail in their monitoring responsibilities. For example, the last audit reports on the financial statements of 22 out of 32 failed finance companies included in this study contained no emphasis of matter paragraph for going concern uncertainty. 